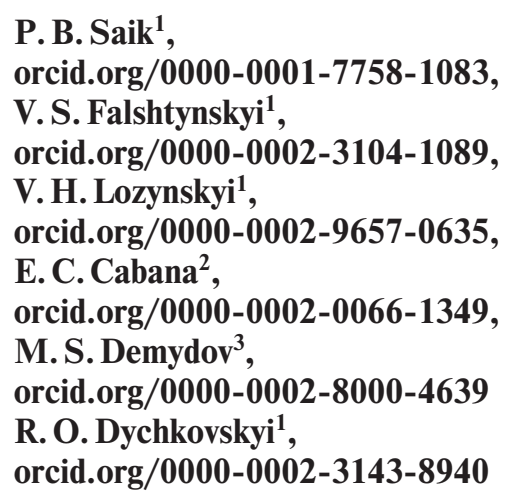

1 - Dnipro University of Technology, Dnipro, Ukraine, e-mail: Dychkovskyi.r.o@nmu.one

2 - National University of Saint Augustine, Arequipa, Peru

3 - Geological Concern "Geobit", Chrzanów, Poland

\title{
EFFICIENCY OF UNDERGROUND GAS GENERATOR IN CONSIDERATION OF THE REVERSE MODE
}

Purpose. Activation of the processes of well underground coal gasification with the consideration of the reverse mode of the underground gas generator based on the balanced state between the oxidizing and reducing zones of the fire face.

Methodology. The underground gas generator efficiency was evaluated based on the analytical and laboratory studies. Analytical substantiation of the implementation of reverse operations in terms of the underground gas generator is based on the quantitative parameters of coal gasification in the oxidizing and reducing zones of the underground gas generator and their advance rates. Laboratory studies were carried out on a stand unit with the modeling of the coal gasification processes.

Findings. Efficiency of the underground gas generator operation by reversing with blowing mixtures has been substantiated, which helps to maintain the balance between its oxidizing and reducing zones. Time periods for the reverse operations have been identified on the basis of the averaged value of concentrations of the combustible generator gases on the outlet from the modeled underground gas generator.

Originality. Dependences of the changes in displacements of the active underground gas generator zones in terms of the implemented reverse of blowing mixture supply have been obtained with the consideration of mining and geological conditions of the occurrence of coal seam $\mathrm{c}_{6}$ of Solenivska site of Donets coalfield. Parameters of the temperature field distribution around the fire face of the underground gas generator have been identified. Correction coefficient $\left(k_{v}\right)$ has been determined, which helps to obtain the data on the advance rate of the oxidizing zone of the underground gas generator with the use of "MTB WUCG" software.

Practical value. A design of the laboratory stand unit for coal gasification has been improved, which simplifies the control of technological processes while studying gasification modes. Operating efficiency of the underground gas generator with the transition to the reverse mode has been substantiated on the basis of energy balance of the active zones of the reaction channel and composition of the generator gas.

Keywords: Donbas, underground gasification, reverse mode, heat field, coal seam, fire face

Introduction. Massive development of the world production and industrial infrastructure results in considerable growth of demand for energy resources [1]. In numerous cases, current problems of the provision of international trade with energy raw materials mean not only certain economic indices of the development; those problems also influence a political situation of the whole regions. A state of both the recognized centers of mineral extraction and interstate infrastructures of the mineral consumption is a clear example. In this context, we can see that in many cases the available considerable reserves of oil, natural gas, coal or uranium do not guarantee economic growth of a state. Not only the Third World countries, but also certain countries with the seemingly developed economy may be the example of such case. The recent events show that rather dramatic wars may unfold in the raw material markets resulting in the recession of countries and redistribution of the elite influences. Today we may be sure to state that in terms of current globalization, the national energy factor is a dominant one, determining the country's future social and production development [2].

In terms of Ukraine, the issues of searching for a stable and reliable source of energy resources are some of the priority ones, whose solution determines the national political and economic development as well [3]. Nowadays, the complex situation in the fuel and energy sector of Ukraine, i.e. in the mining industry, makes us search for cardinally new technolo-

(C) Saik P.B., Falshtynskyi V.S., Lozynskyi V.H., Cabana E.C., Demydov M.S., Dychkovskyi R. O., 2020 gies to obtain energy resources [4]. It should be noted that the emphasis is not always placed in favor of the traditional energetics [5]. Long-term tendencies of the development of our economy, when a considerable share of energy sources was exported from abroad, have appeared to be absolutely incorrect. Thus, today we are dealing with the reorientation for other clean technologies of power generation, which may be developed in sufficient scale irrespective of the export products. In addition, more and more often there arise propositions to unite several mining technologies in terms of one mining enterprise. Such improvements are aimed at maximum mineral extraction from the deposits; in this context, this is performed at the economically expedient level with the consideration of environmental components of the post-mining terrain restoration. One of the promising tendencies in the coal industry development is the creation of a single mining and energy-chemical complex in terms of the mine areas. Key principles of its operation are based on the synthesis of two technologies: traditional extraction of coal and its underground gasification [6].

Implementation of the technology of underground coal gasification at coal enterprises, which are in stagnation or have already completed their production period, helps to prolong their mine producing life [7]. That is possible by developing the coal reserves left for technological, economic, and environmental purposes [8]. Besides, that technology makes it possible to process mining wastes and utilize the surfaced rocks containing sufficient amounts of combustible substances. 
A technology of coal gasification provides efficient adaptivity of the process to a system of mining production by the diversity and intended use of the end product [9]. Certain dynamic change in mining and technical as well as mining and geological conditions of the occurrence of coal reserves is the factor determining the required energy resource type [10]. In this context, the processes of underground coal gasification have not been studied to the full extent so far; moreover, due to a rapid scientific and technological progress, these processes require constant improvements.

Literature review. Over the recent decade, a series of scientific and research studies has been carried out to analyze the problems of the efficiency of gasification process conduct. In particular, paper [11] stresses that to improve a process of UCG activation, it is required to add catalysts (first of all, that is $\mathrm{Fe}$ ) into the blowing mixture and perform variation by pressure; this will result in the increasing content of $\mathrm{CH}_{4}$ up to $14 \%$ in the outgoing mixture. Efficiency of the gasification processes may be also increased considerably by using corresponding catalysts, helping to reduce the temperature in terms of the preservation of high process rate and regulate the product composition. The most widespread catalysts of the coal gasification process are as follows: compounds of alkaline, alkaline-earth, and some transition metals (ruthenium $(\mathrm{Ru})$, cobalt (Co), ferrum (Fe), and nickel (Ni) [12]) and potassium carbonates $\left(\mathrm{K}_{2} \mathrm{CO}_{3}, \mathrm{Na}_{2} \mathrm{CO}_{3}, \mathrm{CaCO}_{3}[13]\right)$. The mentioned compounds are rather limited in terms of their mass production and quite costly to be used as an intermediate product while forming gaseous power-generating fuel during the coal gasification. However, it should be pointed out that the group also includes ferrous oxides. It is also a well-known fact that relying on the current mining techniques, it is the ferrum that is the most available and cheapest metal to be mined in Ukraine.

Those assumptions were proved by the results obtained after the studies dealing with the activation of the gasification processes, which aim was to increase calorific properties of the end gas product [14]. The author of the paper proposes to use different metallurgical slag as the catalysts. It is known that such metal-production by-products contain a considerable iron concentration. Experimental studies prove that adding of ferronickel slag in the amount of $6 \%$ favors the increase of concentration of combustible components in a generator gas by $15 \%$. In this context, carbon is used in its most potential, making it possible to increase the gasification efficiency by almost $23 \%$. Moreover, such activation method may be applied to vary concentrations of certain combustible gases (carbon monoxide, hydrogen, methane and other saturated carbohydrates).

According to the authors of paper [15], it is possible to increase the indices of efficient output of the generator gas usable for further thermal conversion by supplying active components of the blowing along a flexible pipeline through perforated nose pieces into a reaction channel of a gas generator. That interesting engineering solution helps to maintain stable dynamics of the process of temperature field distribution within the rocks and a gas generator. The process is based on the principles of convectional and conductional heat exchange between the gaseous UCG products, fire face, and rock mass [16]. In this context, formation of functionality of the transition and reducing zones depend on the controllability and directionality of the oxidation reactions within the oxidizing zone, which forms a temperature capsule in time and space around a reaction channel, taking into consideration the fire face advance, the gas generator hermiticity, and the heat-capacity and heat-conductivity parameters of the rock [17].

There is a following interesting approach to solve a geomechanical problem of rock mass control within the area of high temperatures. This is a different-mode supply of a blowing mixture aimed at the formation of a two-layer shell of the fritted rocks to provide stability of the reactor during its operation
[18]. Possibility of a cyclic step of the roof rocks caving by adding the heated vapor on argillaceous shales to increase its strength properties has been proved in practice. Thus, lumpiness of the caved roof rocks enlarges as well with its following positive effect on the lowering.

Unsolved aspects of the problem. Irrespective of the considerable number of substantiated studies concerning underground in-situ coal gasification, the obtained results are aimed at the substantiation of technological and technical solutions of the process conduct. Moreover, they are based on the studies of stress-strain state of the rock mass of the underground gas generator by means of both analytical methods [19] and experimental studies carried out under real mine conditions [20], analysis of geofiltration processes [21], volumes and qualitative characteristics of the gas output [22], including calculation of the material-heat balance [23], distribution of temperature field around the fire face [24], and its advance [25]. At the same time, a difference between the advance rates of the chemical reaction zones along the fire face length has not been taken into account while considering the gasification process physics. Due to that fact, the necessity arises to carry out additional studies to substantiate the parameters of advance for the oxidizing and reducing zones of the underground gas generator, basing on the efficiency of the gasification process conduct under the specific mining and geological conditions.

Purpose of the research is to study activation of the processes of well underground coal gasification taking into consideration the reverse mode of the underground gas generator on the basis of the balance between the oxidizing and reducing zones of the underground gas generator.

Research procedure. Experimental studies were carried out in terms of a laboratory unit developed and patented in the NTU "DP". The unit consists of four main elements: testing stand, blowing and gas-outlet systems, and control and measuring equipment.

To reconstruct a physical model, full-scale conditions of the occurrence of coal seam $c_{6}$ of Solenivska site of Donets coalfield (site No.1) was used.

The site is located within the field of the Krasnoarmeisk coalfield, Donetsk oblast, adjoining the north-east slope of the Ukrainian crystalline core-area and stretching along the south-east edge of the Donets ridge. This site also includes the suites of coal seams $C_{6}^{1}, C_{6}, C_{5}^{1}, C_{5}$, and $C_{4}^{2}$.

In terms of its down-dip and up-dip, the suite of seams of site No. 1 is confined with Shevchenkivsky fault No. 1 and Kyrylivsly fault; along its strike to the south, it is confined with Shevchenkivsky fault No. 3. There is a village of Kotliarivka to the west, $5.0 \mathrm{~km}$ from the WUCG site; to the north, there are villages of Muravka and Novomykolayivka, 10 and $12 \mathrm{~km}$ from the site respectively.

There are following dimensions of the site: down-dip $H=1410 \mathrm{~m}$; along the strike to the south $-S=827 \mathrm{~m}$, and to the north $-S=3000 \mathrm{~m}$. On-balance reserves of the coal seams of site No. 1 are $Z=4786.8$ thousand t. Occurrence depth of the coal seams is $72-221 \mathrm{~m}$. Thickness of the coal seams is $m=0.5-0.9 \mathrm{~m}$. Incidence angle is $\alpha=10-19^{\circ}$. Coal grades are $\mathrm{G}$ (gas coal - volatiles $50 \%$ ) and $\mathrm{F}$ (fat coal - volatiles $30 \%$ ).

Filtration properties of the seam are pre-characterized within the range of $0.38-0.62 \mathrm{D}$; the ones of the enclosing rocks are $0.71-1.06 \mathrm{D}$.

Hydrogeological conditions of the site are relatively favorable. The site is isolated by tectonic disturbances down-dip, up-dip, and along the strike from the hydraulic connection with the superposed water-bearing levels. The waters are associated to the limestone and sandstone. The water-bearing level of the Lower Carboniferous deposits is of sheet-like and fractured type with the artesian surface. The head $(H)$ varies from 49.35 to $105.90 \mathrm{~m}$. Coefficient of filtration is $K_{f}=0.0032-$ $0.0914 \mathrm{~m} /$ day. Coefficient of water conductivity is $K=5.28$ $13.30 \mathrm{~m}^{2} /$ day. Expected water inflow into the underground gas generator is $4.5-16.7 \mathrm{~m}^{3} / \mathrm{t}$. Basing on the fact that the sand- 
stones and limestones are confined with the tectonic disturbances, sandstones of the roof contain only minor reserves of static water; and insignificant limestone layers are within the upper layers of the rock mass.

Coal seam $c_{6}$ of the mentioned coalfield site has been taken for the study. The seam is of simple structure; its overall thickness varies from 0.6 up to $0.9 \mathrm{~m}$. In terms of its qualitative characteristics, the coal is power-generating and gas one $(\mathrm{G}-$ gas coal in Ukrainian classification). It is matt with dark lustreous inclusions of fusain; its fracture is uneven. The coal is of medium hardness. Its occurrence is smooth with rock downdip towards the north and north-east at the angle of $10-19^{\circ}$. In terms of the moisture ash-free state $Q^{\text {saf }}$, the highest combustion heat of the coal is $22-24 \mathrm{~mJ} / \mathrm{kg}$ on average; in terms of the dry ash-free state $V^{d a f}$, its volatile-matter content is $22-27 \%$. Table 1 represents the qualitative characteristic of the coal of seam $c_{6}$.

Rocks of the immediate roof are represented mostly by the sandy grey and argillaceous shales of medium $f=3-4$ hardness. Under the effect of high temperatures, those structures form domes, which will provide the gas generator tightness and prevent the gas from its migration within the rock mass. The main roof is mostly represented by the sandstone (grey, with the veinlets of carbon substances) of $f=7-8$ hardness and sandy shales (dark grey, micaceous, interlayered with finegrained sandstone) of medium $f=5$ hardness.

The main water-bearing level is associated to coal formations of fissured-layered type with the stacked surface. The height of the head reaches $55 \mathrm{~m}$ and more. Specific yield is $0.0036-0.067 \mathrm{l} / \mathrm{s}$ with the coefficient of filtration $K_{f}-0.0048-$ $0.7 \mathrm{~m} /$ day.

Taking into consideration the available natural screens, the expected water inflow within the boundaries of the site No. 1 may be up to $5-6 \mathrm{~m}^{3} / \mathrm{t}$. Main water inflow will be observed from the overlying level.

The performed modeling of the processes within the underground gas generator included the preliminary determination of geometrical, mechanical, and kinematic scaled coefficients, which provided the conditions of similarity in the systems of "modeled parameters of a test gas generator - fullscale mining and engineering conditions of the gasification station". Thus, we have obtained the possibilities to get adequate results of the full-scale studies of the heat and material process of gasification for the specific mining and geological conditions with the sufficient degree of confidence.

To simulate a physical model of the underground gas generator, we used coal blocks of $0.2 \times 0.5 \times 0.1 \mathrm{~m}$ geometry and pieces of mine rock mixed with the solution of chamotte earth. The coal-rock mass modeling was performed in two stages. Stage one involved modeling of a coal seam; stage two involved modeling of the overlying thickness and rocks of the immediate and main floor. Increasing hardness of the main roof and floor rocks was provided by the introduction of certain amount of the rock of the metamorphism degree, corresponding to the mine full-scale object, as well as by their adhesion with the cement grouting of A-400 type.

Corresponding openings were formed in the seam to simulate injection, gas-outlet wells, and a gasification channel. Boundaries of a reaction channel were made with the help of coal fractions of $2.5-6.8 \mathrm{~cm}$. They simulated the seam hydro-

Table 1

Thickness, occurrence depth, and reserves in terms of seam $c_{6}$ within the site No. 1

\begin{tabular}{|c|c|c|c|c|}
\hline $\begin{array}{c}\text { Site } \\
\text { number }\end{array}$ & $\begin{array}{c}\text { Occurrence } \\
\text { depth, } \mathrm{m}\end{array}$ & $\begin{array}{c}\text { Thickness, } \\
\mathrm{m}\end{array}$ & $\begin{array}{c}\text { Volume } \\
\text { weight, } \mathrm{t} / \mathrm{m}^{3}\end{array}$ & $\begin{array}{c}\text { Coal reserves, } \\
\text { thousand } \mathrm{t}\end{array}$ \\
\hline 1 & $\frac{72-135}{112}$ & $\frac{0.83-0.95}{0.9}$ & 1.24 & 1192.6 \\
\hline
\end{tabular}

fractures between the development wells. To increase the experimental probability and reliability of the final results, we have provided corresponding heat insulation of a stand unit along the perimeter of the modeled coal-rock mass. Fireclay bricklaying was used as a heat-insulating material.

Parameters of the heat field distribution around the fire face were recorded with the thermal couples mounted right on the modeled rock mass of the roof at the distance of $30 \mathrm{~cm}$ from the coal seam. It was made to avoid their damaging, when they will enter the zone of critical temperatures of the operating georeactor. The data were recorded taking into consideration the heat conductivity of argillaceous shales occurring immediately under the coal seam. The data were sent automatically to the dispatch station; there they were displayed in real time on the computer screen in the form of tables with concrete data and corresponding graphic representation of the temperature changes in time. Two gas analyzers BX-170 (hydrogen) and Casboard-3200L (other outgoing gases) were used to control the qualitative composition of a generator gas.

Analytical studies of the advance rate of a fire face. The authors of the research used "MTB WUCG" software to define the advance rate of the fire face [26]. In this context, analysis of the obtained results concerning the gasification parameters needs clarification.

For instance, in terms of the supply of air blowing $\left(\mathrm{O}_{2}=21 \%\right)$ into the underground gas generator and coal seam parameters $W^{r}=5.8 \%, W^{a}=6.9 \%, A^{c}=12.0 \%, S^{d}=1.6 \%$, $V^{\text {daf }}=24.2 \%, C^{\text {daf }}=80.3 \%, H^{\text {daf }}=5.5 \%, O^{\text {daf }}=7.2 \%$, $N^{r}=5.0 \%, Q^{r}=23.4 \mathrm{~mJ} / \mathrm{kg}, \gamma=1.24 \mathrm{t} / \mathrm{m}^{3}$, it is possible to gasify $2.73 \mathrm{~m}^{3}$ of coal per hour. Under such conditions, the fire face length is $L=30 \mathrm{~m}$, coal seam thickness is $m=1.05 \mathrm{~m}$. Gasification intensity is $I=3.38 \mathrm{t} /$ hour.

The advance rate of the fire face of the underground gas generator is determined as follows, $\mathrm{m}$ /hour

$$
v_{t h}=\frac{I_{v}}{L m}
$$

where $I_{v}$ is the volume intensity of coal gasification, $\mathrm{m}^{3} /$ hour.

The determined advance rate of the fire face $\left(v_{t h}=\right.$ $=0.09 \mathrm{~m}$ /hour) makes it possible to define the amount of coal being gasified per day, month, year and so on. In this context, the software does not take into account the intensity of air mixture output along the blowing well, which affects the rate of chemical reactions near its mouth, zonality of the gasification process, and temperature mode at the coal walls in the fire channel.

In general, Fig. 1 represents a scheme of the idealized conditions of the fire face advance.

Analysis of the analytical studies has shown that it is required to carry out additional experimental studies to obtain

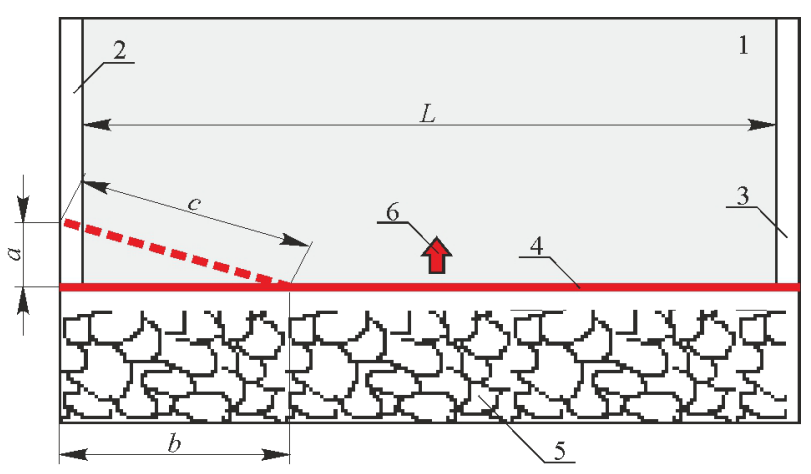

Fig. 1. Idealized scheme of the fire face advance:

1-coal seam; 2 - blowing well; 3 - gas-outlet well; 4 - fire face; 5 - gassed-out space; 6 - direction of the fire face motion; $a$ - amount of oxidizing zone advancing relative to the reducing zone; $b$ - width of the oxidizing zone; $c$ - length of the oxidizing zone 
the operating data as for the advance rate of the fire face of the underground gas generator involving "MTB WUCG" software. This will help to identify the required correction coefficients to determine the advance rates of the fire face depending on the distribution of the chemical reaction zones in it.

Experimental studies on coal gasification in consideration of the reverse mode. While studying a gasification process under laboratory conditions, the modeled coal seam was fired with the help of red-hot coal fractions of $20-40 \mathrm{~mm}$. Additional activation of the process was provided by the supply of blowing enriched with oxygen $\left(\mathrm{O}_{2}=28-40 \%\right)$ with average consumption of $Q=2.9 \mathrm{~m}^{3} / \mathrm{min}$. Direction of the reaction channel burning between the blowing and gas-outlet well coincided with the blowing-supply direction. Temperature mode of the reaction channel was within the range of $584-705^{\circ} \mathrm{C}$; blowing mixture was supplied at the average pressure of $0.3 \mathrm{MPa}$. In terms of such parameters, burning rate of the reaction channel varied from 0.7 to $0.96 \mathrm{~m} /$ hour. The initial stage of the reaction channel burning was performed in the forced mode of the blowing supply; transition to the combined mode with the use of flue gas duct made it possible to reduce a pressure of the blowing mixture supply by almost $45 \%$ and increase the burning rate by $27 \%$.

Formation of the active zones and heat intensification of the reaction channel of the gas generator model were provided by the reverse of blowing supply from the blowing and gasoutlet wells. The fire face was in the temperature range of 695$1004{ }^{\circ} \mathrm{C}$. Average pressure of the blowing mixture supply was $0.24 \mathrm{MPa}$. That helped to form the oxidizing, transition, and reducing zones of the gas generator. Analysis of the heat field distribution within the fire face roof has made it possible to determine the distribution parameters of those zones. Lengths of the zones were as follows: oxidizing zone $-27-33 \%$; transition zone $-4-7 \%$, and reducing zone $-60-69 \%$.

Combined firing of the seam and formation of the reaction channel helped to bring the gas generator in the stable gasification mode in 3 hours. In 3 hours 40 minutes after the experiment beginning, the temperature within the range of $590-685^{\circ} \mathrm{C}$ was recorded in the oxidizing zone of the fire face at the distance of $0.2 \mathrm{~km}$ from the blowing supply point. At the distance of $0.76 \mathrm{~m}$ from the blowing supply point, the temperature within the fire face length was $884-1007^{\circ} \mathrm{C}$. Oxygen content did not exceed $1.5 \%$; carbon dioxide content was $12.6 \%$.

According to the observations, in 5 hours 35 minutes from the experiment beginning, heating of the roof rocks above the fire face at the distance of $0.1 \mathrm{~m}$ from the blowing supply point was $412-470{ }^{\circ} \mathrm{C}$; at the distance of $0.62 \mathrm{~m}$, the temperature was $566-734{ }^{\circ} \mathrm{C}$; at the distance of $0.87 \mathrm{~m}$, the temperature was $664-750{ }^{\circ} \mathrm{C}$; and at the distance of $1.18 \mathrm{~m}$, the temperature was $450-529{ }^{\circ} \mathrm{C}$. The generator gas output was $2.1-2.4 \mathrm{~m}^{3} / \mathrm{min}$ with the lowest temperature of $2.5-$ $7.2 \mathrm{~mJ} / \mathrm{m}^{3}$.

Along with the coal seam gasification, changes in a series of technological and technical parameters were observed: of the gassed-out space $\left(0.12-3.86 \mathrm{~m}^{2}\right)$; changes in the gas generator hermiticity; increasing lengths of the oxidizing zone and the reaction channel; growing vertical and horizontal fissility; accelerating advance rates of the active zones of the gas generator. That is connected with the displacement of the rock layers of the coal seam roof.

In 10 hours of the study, critical destabilization of the coal gasification process was observed. That resulted in the violation of the temperature mode along the fire face length; changes in the parameters of the syngas yield on its output from the gas-outlet well; and increase in the ballast elements in the gascondensate product (Table 2).

To solve the problem, during the experiment the authors made a solution of gas generator transition to the reverse mode. In this context, impulse blowing supply was applied additionally for the efficient change of the active gas generator
Table 2

Composition of the fuel elements of the generator gas

\begin{tabular}{|c|c|c|c|c|}
\hline \multirow{2}{*}{$\begin{array}{c}\text { Hour, } \\
\text { hour:min }\end{array}$} & $\begin{array}{c}\text { Composition of the fuel } \\
\text { elements of the generator gas } \\
\text { during the experiment, }\end{array}$ & $\begin{array}{c}\text { Calorific value of the } \\
\text { generator gas, } \\
\text { mJ } / \mathrm{m}^{3}\end{array}$ \\
\cline { 2 - 4 } & $\mathrm{CH}_{4}$ & CO & $\mathrm{H}_{2}$ & \multirow{3}{|c|}{} \\
\hline \multicolumn{5}{|c|}{ Mode of burning and formation of the reaction channel } \\
\hline $10: 00$ & 0.00 & 0.00 & 0.00 & 0.00 \\
\hline $10: 30$ & 0.12 & 0.16 & 0.30 & 0.22 \\
\hline $11: 00$ & 0.70 & 0.91 & 0.88 & 0.46 \\
\hline $11: 30$ & 0.60 & 2.03 & 0.94 & 0.58 \\
\hline $12: 00$ & 0.42 & 2.16 & 1.85 & 0.79 \\
\hline Mode of formation of the active zones of the reaction channel \\
\hline $12: 30$ & 0.67 & 2.94 & 2.60 & 1.52 \\
\hline $13: 00$ & 0.74 & 4.48 & 4.02 & 2.00 \\
\hline $13: 30$ & 0.77 & 4.92 & 4.51 & 2.11 \\
\hline $14: 00$ & 0.82 & 5.60 & 5.77 & 2.30 \\
\hline \multicolumn{5}{|c|}{ Mode of the coal seam gasification } \\
\hline $14: 30$ & 0.97 & 6.15 & 6.21 & 2.45 \\
\hline $15: 00$ & 0.95 & 6.82 & 7.06 & 2.52 \\
\hline $15: 30$ & 1.23 & 10.46 & 9.89 & 3.38 \\
\hline $16: 00$ & 3.81 & 12.58 & 11.43 & 4.57 \\
\hline $16: 30$ & 4.73 & 14.80 & 13.11 & 5.01 \\
\hline $17: 00$ & 5.28 & 14.09 & 16.36 & 5.92 \\
\hline $17: 30$ & 6.53 & 14.45 & 18.29 & 6.34 \\
\hline $18: 00$ & 6.91 & 14.40 & 19.68 & 7.28 \\
\hline $18: 30$ & 6.12 & 14.02 & 18.40 & 6.02 \\
\hline $19: 00$ & 5.26 & 11.04 & 15.00 & 4.73 \\
\hline $19: 30$ & 4.91 & 10.53 & 14.28 & 4.05 \\
\hline Destabilization of the process, reverse mode, maintenance of the \\
\hline optimal gasification parameters during extinction \\
\hline $20: 00^{*}$ & 3.49 & 16.02 & 9.68 & 4.08 \\
\hline $20: 30^{*}$ & 3.53 & 15.66 & 10.32 & 4.10 \\
\hline $21: 00^{* *}$ & 3.62 & 15.10 & 10.94 & 4.04 \\
\hline $21: 30^{* *}$ & 3.86 & 14.78 & 11.05 & 4.00 \\
\hline $22: 00^{* *}$ & 4.10 & 13.53 & 12.20 & 3.88 \\
\hline $22: 30^{* *}$ & 4.20 & 14.36 & 11.80 & 4.06 \\
\hline
\end{tabular}

* - destabilization of the gasification process,

** - beginning of reverse, going out from the extinction mode

zones (oxidizing and reducing). That helped to level the fire face, restore the reaction channel length specified by the analytical studies, and stabilize the qualitative parameters of the coal seam gasification products.

Physicochemical processes connected with the changes in the chemical composition and properties of coal as well as design peculiarities of the underground gas generator make up the important and diverse group of the processes of underground coal gasification. Controllability, safety, and processability of the syngas generation depend on the interaction (balanced state) of the "underground generator" system, rates of chemical reactions and physical processes during the coal seam gasification. Transition of the gas generator to the reverse mode results both in changed supply and consumption of the substance masses and in their changed volumetric indices in this process. 
In terms of the reverse gas generator mode, changes in the temperature parameters of the oxidizing, transition, and reducing zones along the fire face length were recorded during the experiment (Fig. 2). In this context, parameters of the zones distributions were given on the basis of the analytical studies. Pressure of the blowing supply experienced changes from $0.5 \mathrm{MPa}$ at the initial stage of reverse operation to $0.18 \mathrm{MPa}$ in terms of stabilization of the coal seam gasification process.

According to the research results, destabilization of the gasification process takes place in terms of the oxidizing zone advancing relative to the reducing one by more than $50 \%$. That results in the heat energy transfer from thermochemical reactions into the reducing zone of the gas generator. The reverse implementation levels the fire face and activates the gasification processes along with the creation of the conditions for the gasification process balancing. Graphs of changes in the geometry of active fire face zones depending on the gasification process duration were obtained on the basis of the analytical and experimental data (Fig. 3).

Analysis of the data (Fig. 3) shows that in terms of oneday conduct of the gasification process, average advancing of the oxidizing zone relative to the reducing one is $0.6 \mathrm{~m}$; near the mouth of the development wells (blowing, gasoutlet), it is $0.8 \mathrm{~m}$. In this context, length of the oxidizing zone $\left(c_{1}=9 \mathrm{~m}\right)$ has minor effect on the yield of combustible generator gases. During the second day of the gasification process, advancing value increases almost twofold. Moreover, the length of the oxidizing zone $\left(c_{2}\right)$ increases sharply up to $9.5 \mathrm{~m}$. This is explained by the grown intensity of the gasification process owing to the preliminary heating of the coal-rock mass. The third day shows that the average advancing value is $2.4 \mathrm{~m}$ and the length of the oxidizing zone is $11.2 \mathrm{~m}$

According to the data on the yield of combustible gases (Table 1) and full-scale conditions of the gasification process conduct, there is process destabilization after the second day. Thus, according to the research data, gasification process will be conducted in the most efficient way in terms of $\frac{a}{c} \leq 0.13$, where $a$ is the oxidizing zone advancing relative to the reducing zone, $\mathrm{m}$; $c$ is the oxidizing zone length.

Consequently, in terms of the oxidizing zone length of $10.2 \mathrm{~m}$ and basing on the data concerning the yield of combustible generator gases, we may confirm the efficiency of the gasification process conduct.

The experimental data made it possible to specify the advance rates of the oxidizing and reducing zones of the underground gas generator. In this context, convergence between the identified analytical rate $(0.09 \mathrm{~m} /$ hour $)$ is up to $\eta=74 \%$ being $0.07 \mathrm{~m} /$ hour. The value corresponds to the average rate of the reducing zone advance being $1.6 \mathrm{~m} /$ day. According to the analysis of the displacement of the fire face active zones (Fig. 3), the average advance rate of the oxidizing zone is, $\mathrm{m} /$ day

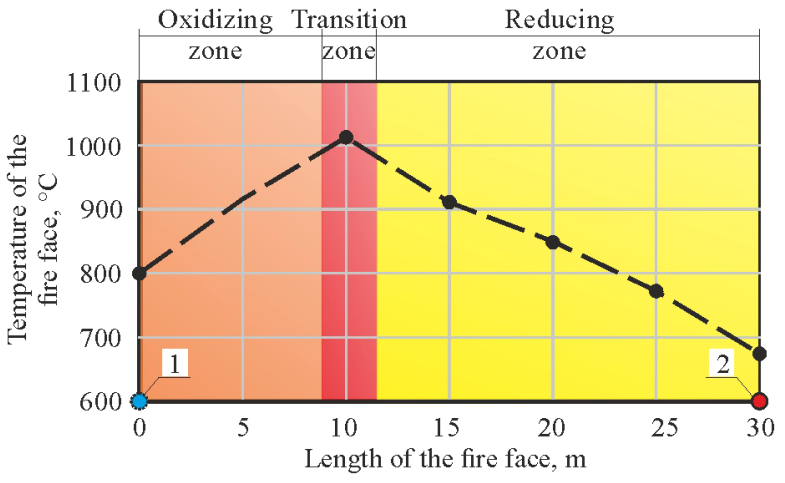

$a$

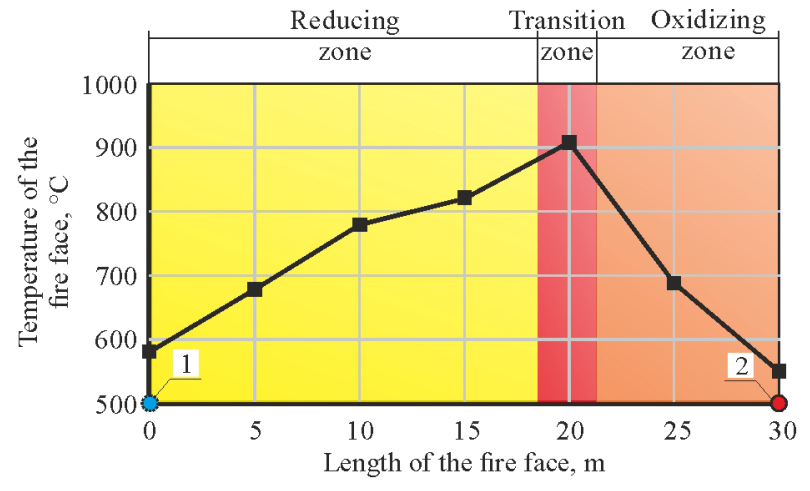

$b$

Fig. 2. Parameters of distribution of the fire face temperatures before (a) and after ( $b$ ) the reverse mode:

1 - blowing well; 2 -gas-outlet well

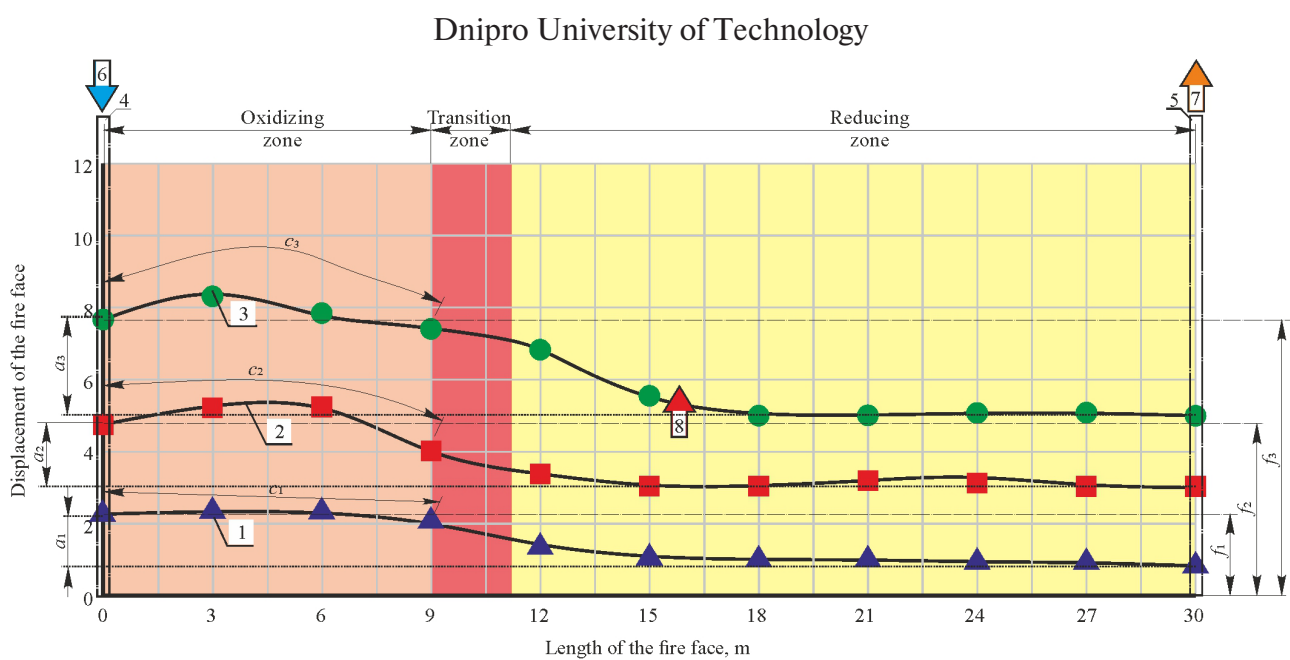

Fig. 3. Graph of displacement of the active fire face zones along the length of the underground gas generator column depending on the duration of gasification process:

1 - one day; 2 - two days; 3 - 3 days; 4 - position of the blowing well; 5 - position of the gas-outlet wells; 6 - direction of the blowing mixture motion; 7 - direction of the gas-outlet mixture motion; 8 - direction of the fire face motion 


$$
v_{a v_{\text {vi }}}=\frac{\frac{\left(f_{1_{0}}+f_{1_{3}}+f_{1_{6}}+f_{1_{9}}\right)}{n T_{1}}+\frac{\left(f_{2_{0}}+f_{2_{3}}+f_{2_{6}}+a_{29}\right)}{n T_{2}}+\frac{\left(f_{3_{0}}+f_{3_{3}}+f_{3_{6}}+f_{3_{9}}\right)}{n T_{3}}}{3}=2.54,
$$

where $f_{1_{0}}-f_{1_{0}} ; f_{2_{0}}-f_{2_{9}} ; f_{3_{0}}-f_{3_{0}}$ are locations of the oxidizing zone behind the fire face length at the distance of $0,3,6$, and $9 \mathrm{~m}$ from the blowing well, $\mathrm{m} ; T_{1}, T_{2}, T_{3}$ are durations of the gasification process (one, two, and tree days respectively); $n$ is the number of measuring points within the oxidizing zone.

The determined advance rate of the oxidizing zone of the underground gas generator helps to obtain the correction coefficient

$$
k_{v}=\frac{100 \cdot v_{e x_{o x}}}{\eta \cdot v_{t h}}=1.65,
$$

where $v_{e x_{o x}}$ is the average experimental advance rate of the oxidizing zone of the underground gas generator, $\mathrm{m} /$ hour; $v_{t h}$ is the theoretical advance rate of the underground gas generator obtained during the calculations involving "MTB WUCG", $\mathrm{m} /$ hour; $\eta$ is the convergence between the theoretical and experimental studies, $\%$.

Thus, having obtained the values of theoretical advance rate of the fire face by means of "MTB WUCG" software and having applied the correction coefficient $\left(k_{v}\right)$, it is possible to define the advance rate of the oxidizing zone of the underground gas generator.

Basing on the performed analytical and experimental studies, the authors of the research have improved the laboratory unit for studying the coal gasification processes. A reverse T-fitting has been developed and connected to the system of blowing-mixture supply and generator-gas output. This will help to perform the reverse operations automatically during the study of gasification processes without disconnecting the blowing and gas-outlet flexible pipelines.

Moreover, the obtained results have allowed elaborating the design documentation for the development of a laboratory unit to study processes of thermochemical transformations of the carbon-bearing raw material. Development of such a unit meets the main trends of the research of the laboratory of thermochemical transformation technologies of the Sharing Center "Innovative Geoenergetics" of the Dnipro University of Technology. Further studies are planned to substantiate the parameters and develop innovative technology of thermochemical transformation of the carbon-bearing raw materials in the closed technological and ecological cycles. The technology is aimed at the maximum efficient obtaining of high-quality power-generating (generator gas, heat energy) and chemical (coal-tar resins, ammonia, phenols, sulphur and other) products as well as at the formation of a complex of linked solutions to utilize industrial and domestic wastes on the basis of georeactor systems that will help to minimize and/or eliminate the cancerogenic emissions formed from the gas condensate, major part of which enters the environment.

Conclusion. The carried out research on the in-situ coal gasification processes makes it possible to identify certain changes in the geometry of the fire face and in its temperature field of the chemical reaction zones in time and space. This helps to make prompt decisions as for the required changes in the operating modes of the underground gas generator.

Transition of the underground gas generator to the reverse mode on the basis of the analysis of combustible gases yield results in the restoration of the stable gasification mode.

Parameters of the changes in the fire face advance rates relative to the zones of chemical reactions in it have been substantiated. The correction coefficient $\left(k_{v}\right)$ has been proposed. The coefficient allows obtaining the data on the advance rate of the oxidizing zone of the underground gas generator with the application of "MTB WUCG" software.

Acknowledgements. This work was supported by the Ministry of Education and Science of Ukraine, grant No. 0119U000248 and No. 0120U102084.

\section{References.}

1. Sribna, Y., Trokhymets, O., Nosatov, I., \& Kriukova, I. (2019). The globalization of the world coal market - contradictions and trends. E3S Web of Conferences, (123), 01044. https://doi.org/10.1051/e3sconf/201912301044.

2. Sekerin, V., Dudin, M., Gorokhova, A., Bank, S., \& Bank, O. (2019). Mineral resources and national economic security: current features. Mining of Mineral Deposits, 13(1), 72-79. https://doi.org/10.33271/mining13.01.072.

3. Pivnyak, G. G., \& Shashenko, O.M. (2015). Innovations and safety for coal mines in Ukraine. Naukovyi Visnyk Natsionalnoho Hirnychoho Universytetu, (6), 118-121.

4. Piwniak, G. G. (2017). Limits to economic viability of extraction of thin coal seams in Ukraine. Technical, Technological and Economic Aspects of Thin-Seams Coal Mining, 129-132. https://doi.org/10.1201/noe0415436700.ch16.

5. Khomenko, O., Tsendjav, L., Kononenko, M., \& Janchiv, B. (2017). Nuclear-and-fuel power industry of Ukraine: production, science, education. Mining of Mineral Deposits, 11(4), 86-95. https://doi.org/10.15407/mining11.04.086.

6. Basu, R. (2017). Evaluation of some renewable energy technologies. Mining of Mineral Deposits, 11(4), 29-37. https://doi. org/10.15407/mining11.04.029.

7. Medianyk, V. (2020). Solutions multivariance about designing new levels of coal mines. Rudarsko Geolosko Naftni Zbornik, 35(2). Accepted paper. https://doi.org/10.17794/ rgn.2020.2.3.

8. Kalybekov, T., Rysbekov, K. B., Toktarov, A.A., \& Otarbaev, O. M. (2019). Underground mine planning with regard to preparedness of mineral reserves. Mining Informational and Analytical Bulletin, (5), 34-43.

9. Bondarenko, V., Tabachenko, M., \& Wachowicz, J. (2015). Possibility of production complex of sufficient gasses in Ukraine. New Techniques and Technologies in Mining, 113-119. https://doi.org/10.1201/b11329-19.

10. Adjiski, V., Despodov, Z., Mirakovski, D., \& Serafimovski, D. (2019). System architecture to bring smart personal protective equipment wearables and sensors to transform safety at work in the underground mining industry. Rudarsko Geolosko Naftni Zbornik, 34(1), 37-44. https://doi.org/10.17794/ rgn.2019.1.4

11. Smoliński, A. (2018). Mathematical and Geomechanical Model in Physical and Chemical Processes of Underground Coal Gasification. Solid State Phenomena, (277), 1-16. https:// doi.org/10.4028/www.scientific.net/ssp.277.1.

12. Smoliński, A. (2019). Characteristic of Possible Obtained Products during the well Underground Coal Gasification. Solid State Phenomena, (291), 52-62. https://doi.org/10.4028/ www.scientific.net/ssp.291.52.

13. Hwang, S.C., Kim, S.K., Park, J.Y., Lee, D. K., Lee, S. H., \& Rhee, Y.W. (2014). Kinetic study on Low-rank Coal Including $\mathrm{K}_{2} \mathrm{CO}_{3}, \mathrm{Na}_{2} \mathrm{CO}_{3}, \mathrm{CaCO}_{3}$ and Dolomite Gasification under $\mathrm{CO}_{2}$ Atmosphere. Clean Technology, 20(1), 6471. https://doi.org/10.7464/ksct.2014.20.1.064.

14. Subbotin, A.N., Tarazanov, A.S., \& Orlova, K.Y. (2016). Numerical analysis of the underground coal gasification syngas composition in dependence to supplied oxidizer properties. International Forum on Strategic Technology (IFOST), 303-307. https://doi.org/10.1109/ifost.2016.7884253. 
15. Falshtynskyi, V., Saik, P., Lozynskyi, V., Dychkovskyi, R., \& Petlovanyi, M. (2018). Innovative aspects of underground coal gasification technology in mine conditions. Mining of Mineral Deposits, 12(2), 68-75. https://doi.org/10.15407/mining12.02.068.

16. Falshtynskyi, V.S., Dychkovskyi, R. O., Saik, P.B., Lozynskyi, V. H., \& Cabana, E. C. (2017). Formation of thermal fields by the energy-chemical complex of coal gasification. Naukovyi Visnyk Natsionalnoho Hirnychoho Universytetu, (5), 36-42.

17. Golovchenko, A. (2020). Some aspects of the control for the radial distribution of burden material and gas flow in the blast furnace. Energies, 13(4), 923-926. https://doi. org/10.3390/en13040923.

18. Dychkovskyi, R. O. (2015). Forming the bilayer artificially shell of georeactor in underground coal gasification. Naukovyi Visnyk Natsionalnoho Hirnychoho Universytetu, (5), 37-42.

19. Tabachenko, M. (2016). Substantiating parameters of stratification cavities formation in the roof rocks during underground coal gasification. Mining of Mineral Deposits, 10(1), 16-24. http://dx.doi.org/10.15407/mining10.01.016.

20. Prusek, S., Lubosik, Z., Rajwa, S., Walentek, A., \& Wrana, A. (2017). Geotechnical monitoring of rock mass and support behaviour around the UCG georeactor: Two case studies in Polish coal mining industry. International Conference on Ground Control in Mining, 321-328.

21. Sadovenko, I., Zagrytsenko, A., Podvigina, O., \& Dereviagina, N. (2016). Assessment of environmental and technical risks in the process of mining on the basis of numerical simulation of geofiltration. Mining of Mineral Deposits, 10(1), 3743. http://dx.doi.org/10.15407/mining 10.01.037.

22. Yun, Z., Jianfang, S., \& Zhongchun, L. (2019). Study of numerical simulation method modelling gas injection into fractured reservoirs. Mining of Mineral Deposits, 13(2), 41-45. https://doi.org/10.33271/mining13.02.041.

23. Lozynskyi, V., Saik, P., Petlovanyi, M., Sai, K., Malanchuk, Z., \& Malanchyk, Ye. (2018). Substantiation into mass and heat balance for underground coal gasification in faulting zones. Inzynieria Mineralna, 19(2), 289-300. http://doi. org/10.29227/IM-2018-02-36.

24. Wang, J., Wang, Z., Xin, L., Xu, Z., Gui, J., \& Lu, X. (2017). Temperature field distribution and parametric study in underground coal gasification stope. International Journal of Thermal Sciences, (111), 66-77. https://doi.org/10.1016/j.ijthermalsci.2016.08.012.

25. Mallett, C., \& Zhang, J. (2017). Gasifier face advance in underground coal gasification. Coal-Energy, Environment and Sustainable Development, PCC.

26. Lozynskyi, V., Dychkovskyi, R., Saik, P., \& Falshtynskyi, V. (2018). Coal Seam Gasification in Faulting Zones (Heat and Mass Balance Study). Solid State Phenomena, (277), 66-79. https://doi.org/10.4028/www.scientific.net/ SSP.277.66.

\section{Ефективність роботи підземного газогенератора з урахуванням реверсного режиму}

\section{П. Б. Саїк1 , В. С. Фальштинський 1 , В. Г. Лозинський ${ }^{1}$, Е. К. Кабана ${ }^{2}$, М. С. Демидов ${ }^{3}$, Р. О. Дичковський}

1 - Національний технічний університет «Дніпровська політехніка», м. Дніпро, Україна, e-mail: Dychkovskyi.r.o@ nmu.one

2 - Університет Святого Августина, м. Арекіпа, Перу

3 - Геологічний консорціум «Геобіт», м. Хжанув, Польща

Мета. Активізація процесів свердловинної підземної газифікації вугілля з урахуванням реверсного режиму підземного газогенератора на основі збалансованості між окислювальною та відновлювальною зонами вогневого вибою.

Методика. Ефективність роботи підземного газогенератора оцінювалась на основі проведення аналітичних і лабораторних досліджень. Аналітичне обгрунтування впровадження реверсних робіт у підземному газогенераторі базувалось на основі кількісних параметрів газифікації вугілля в окислювальній та відновлювальній зонах газогенератора та швидкостях їх посування. Лабораторні дослідження проводились на стендовій установці з моделювання процесів газифікації вугілля.

Результати. Обгрунтована ефективність роботи підземного газогенератора шляхом реверсування дуттьовими сумішами, що дозволяє зберігати баланс між його окислювальною й відновлювальною зонами. На основі усередненого значення концентрацій горючих генераторних газів на виході із змодельованого підземного газогенератора встановлені часові проміжки 3 ведення реверсних робіт.

Наукова новизна. Отримані залежності зміни переміщення активних зон підземного газогенератора за умови встановлення реверсу подачі дуттьової суміші з урахуванням гірничо-геологічних умов залягання вугільного пласта $c_{6}$ ділянки «Соленівська» Донецького кам'яновугільного басейну. Встановлені параметри розповсюдження температурного поля навколо вогневого вибою підземного газогенератора. Визначено поправочний коефіцієнт $\left(k_{v}\right)$, що дозволяє отримувати дані щодо швидкості посування окислювальної зони підземного газогенератора, із використанням програмного забезпечення «МТВ СПГВ».

Практична значимість. Удосконалена конструкція лабораторної стендової установки з газифікації вугілля, що спрощує управління технологічними процесами при дослідженні режимів газифікації. Обгрунтована ефективність роботи підземного газогенератора 3 переходом до реверсного режиму на основі енергетичного балансу активних зон реакційного каналу та складу генераторного газу.

Ключові слова: Донбас, підземна газифікаиія, реверсний режим, теплове поле, вугільний пласт, вогневий вибій

\section{Эффективность работы подземного газогенератора с учетом реверсного режима}

\section{П. Б. Саик ${ }^{1}$, В. С. Фальштынский ${ }^{1}$ В. Г. Лозинский ${ }^{1}$, Э. К. Кабана ${ }^{2}$, М. С. Демидов ${ }^{3}$, Р. Е. Дычковский ${ }^{1}$ \\ 1 - Национальный технический университет «Днепров- ская политехника», г. Днепр, Украина, e-mail: Dychkovskyi.r.o@nmu.one \\ 2 - Университета Святого Августина, г. Арекипа, Перу 3 - Геологический консорциум «Геобит», г. Хжанув, Польша}

Цель. Активизация процессов скважинной подземной газификации угля с учетом реверсного режима подземного газогенератора на основе сбалансированности между окислительной и восстановительной зонами огневого забоя.

Методика. Эффективность работы подземного газогенератора оценивалась на основе аналитических и лабораторных исследований. Аналитическое обоснование внедрения реверсных работ в подземном газогенераторе базировалось на основе количественных параметров газификации угля в окислительной и восстановительной зонах газогенератора и скоростях их подвижки. Лабораторные исследования проводились на стендовой установке по моделированию процессов газификации угля. 
Результаты. Обоснована эффективность работы подземного газогенератора реверсированием дутьевыми смесями, что позволяет сохранять баланс между его окислительной и восстановительной зонами. На основе усредненного значения концентрации горючих генераторных газов на выходе из смоделированного подземного газогенератора установлены временные промежутки ведения реверсных работ.

Научная новизна. Получены зависимости изменения перемещения активных зон подземного газогенератора при условии установления реверса подачи дутьевой смеси с учетом горно-геологических условий залегания угольного пласта $c_{6}$ участка «Соленовский» Донецкого каменноугольного бассейна. Установлены параметры распространения температурного поля вокруг огневого забоя подземного газогенератора. Определен поправочный коэффициент $\left(k_{v}\right)$, что позволяет получать данные о скорости подвигания окислительной зоны подземного газогенератора, с использованием программного обеспечения «МТВ СПГУ».

Практическая значимость. Усовершенствована конструкция лабораторной стендовой установки по газификации угля, что упрощает управление технологическими процессами при исследовании режимов газификации. Обоснована эффективность работы подземного газогенератора с переходом в реверсный режим на основе энергетического баланса активных зон реакционного канала и состава генераторного газа.

Ключевые слова: Донбасс, подземная газификация, реверсный режим, тепловое поле, угольный пласт, огневой забой

Recommended for publication by V.I. Bondarenko, Doctor of Technical Sciences. The manuscript was submitted 27.12.19. 